\title{
Environmental Control of the Course of Development in Dictyostelium discoideum
}

\author{
BY M. I. KRICHEVSKY* AND BARBARA E. WRIGHT \\ Section on Enzymes, National Heart Institute, National Institutes \\ of Health, Bethesda 14, Maryland
}

(Received 10 December 1962)

\begin{abstract}
SUMMARY
Dictyostelium discoideum uses a wide variety of extracellular materials to accelerate the rate of morphogenesis. The stimulants of morphogenesis do not appear to exert their effect through the action of such factors as buffering, ionic strength, tonicity of the medium, or chelation.

Both glucose and histidine stimulate the rate of incorporation of amino acids into protein but at differing stages of development. Glucose stimulates throughout differentiation while histidine shows maximal stimulatory ability at preculmination (i.e. the stage just prior to complete fructification). The two compounds exhibit a mutual antagonism when added together.

It is concluded that glucose is probably acting as a primary energy source, whereas histidine is not acting in this manner or as a limiting amino acid for protein synthesis.
\end{abstract}

\section{INTRODUCTION}

During the life cycle of the cellular slime mould Dictyostelium discoideum, individual myxamoebae multiply on a rich medium at the expense of a bacterium such as Escherichia coli. This is the only stage of the life cycle in which growth, or an increase in protoplasm, occurs. When the bacterial portion of the food supply is gone, thousands of individual amoebae aggregate to form a multicellular pseudoplasmodium. After a period of migration, the pseudoplasmodium culminates to form the final fruiting body, or sorocarp, which is composed of a mass of spores resting on a stalk of cellulose-encased cells. For a detailed discussion of the morphogenesis of $D$. discoideum see Bonner (1959).

The investigations described here are an outgrowth of those of Bradley, Sussman \& Ennis (1956), who found that histidine enhanced both the efficiency (i.e. the number of aggregation centres formed, per unit of cell population, as well as the minimum population density required for any centre formation) and rate of the aggregative process.

\section{METHODS}

Microbiological. The myxamoebae of Dictyostelium discoideum were grown on a complex solid medium (Bonner, 1947) on living Escherichia coli. After the growing amoebae had essentially cleared the agar surface of bacteria they were washed off

* Present address : Laboratory of Microbiology, National Institute of Dental Research, National Institutes of Health, Bethesda 14, Maryland. 
with cold distilled water, separated from residual bacteria (as determined microscopically) by repeated light centrifugation and resuspended in cold distilled water before transfer to $\mathbf{2 . 5} \%$ agar plates. When it was desired to incubate the cells further in an aqueous environment (as opposed to the agar surface), the myxamoebae were finally suspended in a cold salt solution (Bonner, 1947) instead of water. Small amounts of amoebae were harvested from standard Petri dishes while larger numbers of cells were obtained from covered aluminium cookie sheets measuring $15 \times 10 \times 1$ in.

Morphogenetic experiments. In testing the effect of a substance on the developmental process, the material was incorporated into $10 \mathrm{ml}$. of either $2.5 \%$ washed agar (10 volumes of distilled water) (Bradley et al. 1956) or $2.5 \%$ Difco Noble agar. On the day preceding the actual experiment, the agar was poured into a standard $9 \mathrm{~cm}$. diam. Petri dish. The vegetative amoebae obtained from one Petri dish culture, prepared as outlined above, were suspended in a final volume of $10 \mathrm{ml}$. of cold distilled water. Six droplets of $0.01 \mathrm{ml}$. each were placed on the agar surface of each test plate without being spread. Thus the cell population and density could be maintained constant (Bradley et al. 1956). The $\mathrm{pH}$ was initially $6 \cdot 2$ except where noted.

The test plates were incubated at $22^{\circ}$ for a time period (usually $20-24 \mathrm{hr}$.) such that only a small fraction of the ultimately possible mature sorocarps had formed on the surface of the control plates (i.e. those with nothing added to the $2.5 \%$ agar). After incubation, the number of sorocarps as well as the total number of bodies at all stages of development (from definite aggregation through mature sorocarp formation) were counted in each spot and totalled for each plate.

The greatest contrast in the degree of sorocarp formation between control and experimental plates is observed when the control plates have just commenced fruiting. Since the fruiting process is not complete when the counts are made, any change in the rate of development would be reflected in the number of sorocarps observed. In most cases studied, the stimulatory effect of a given material was qualitatively the same regardless of whether the total number of mature sorocarps, the total number of developing centres, or the ratio of sorocarps to centres was considered. (The few exceptions noted are pointed out in the Results section). For all three criteria to yield the same qualitative results, changes in the rate of development as a whole must be a major factor in the observed results. Even though the population densities were not adjusted to a fixed value from experiment to experiment, the standard procedure used for preparing the amoebae suspensions gave populations which operationally fell well within the limits given by Bonner \& Dodd (1962).

If one waits long enough, the number of sorocarps should be the same in all plates when fruit formation is complete. This was found to be so with most of the conditions used in this study. An example may be found in the data in Fig. 4. On plates containing $0.04 \mathrm{M}$-histidine plus $4 \times 10^{-3} \mathrm{M}$ or more phosphate as well as the plate containing $1 \times 10^{-2} \mathrm{M}$-phosphate alone, fruit formation was complete. The number of sorocarps is essentially the same in all cases. Therefore, differences in numbers of sorocarps prior to complete fructification would reflect changes in rate of morphogenesis.

The average $\%$ standard error for all the data presented in this paper was found 
by: (a) computing the standard error of the mean of the sorocarps found in the six drops on each plate; $(b)$ converting this error to a \% of each mean; $(c)$ averaging these \% errors by multiplying together and taking the $N$ th root. By this method, the average $\%$ error was found to be a maximum of $23.6 \%$. This figure was derived by assuming that all the plates exhibiting no mature sorocarps had a $\%$ standard error of $100 \%$. If these samples are omitted from the calculation, then the average \% error is $19 \%$. As might be expected, those plates exhibiting the greatest number of mature sorocarps (i.e. those stimulated to the greatest extent) were most reliable, having an average \% standard error (with more than 50 sorocarps) of $8-15 \%$.

Isotope incorporation experiments. Two types of incubations were performed to test the effect of histidine and/or glucose on the ability of Dictyostelium discoideum to incorporate isotopically-labelled amino acids into protein. In all experiments, approximately $4 \%$ of the washed amoebae obtained per cookie sheet were incubated in each Petri dish. The cells were either: $(a)$ suspended in Bonner's salt solution $\left(0 \cdot 6 \mathrm{~g} . \mathrm{NaCl} ; 0 \cdot 75 \mathrm{~g} . \mathrm{KCl} ; 0 \cdot 3 \mathrm{~g} . \mathrm{CaCl}_{2}\right.$ per litre of distilled water $)$ and all materials subsequently added were also dissolved in the salt solution, or $(b) 0.4 \mathrm{ml}$. of cells suspended in cold distilled water were spread on the surface of washed agar and distilled water was used as the diluent for all substances. In the former system differentiation could proceed only through the aggregation stage, so that long term experiments were carried out in the agar system. Where comparable experiments were performed, no qualitative differences were observed between the two incubation systems.

After pre-incubating the organisms for varying lengths of time, the substance to be tested was added along with the tracer materials $(0.5 \mu \mathrm{C}$. $/$ sample; $0.65 \mu \mathrm{g}$. amino acids). Incubation was at either $19^{\circ}$ or $22^{\circ}$ for the times indicated, and when complete an equal volume of $6 \%$ trichloroacetic acid was added. The protein was purified by the method outlined by Wright \& Anderson (1960 b). When incorporation of tracer into the organism's soluble pool was to be determined, the cells were washed three times with the salt solution before the trichloroacetic acid was added. In this case, the acid supernatant was retained for counting.

It should be pointed out that such incorporation does not represent a net protein synthesis. While both protein synthesis and protein degradation take place during morphogenesis, the net effect is one of degradation (Wright \& Anderson, 1960a). Although the term 'protein synthesis' will be used hereafter, it is obvious that any effects on the amounts of isotopically labelled amino acids in protein are a resultant of effects on both protein synthesis as well as degradation.

The incorporation of isotopically labelled amino acids into protein in the continued presence of histidine was found to be highly variable and confusing when the simple specific activities were considered. This appears to be due to an inhibition by exogenous histidine, at high levels, of the incorporation of extracellular amino acids into the free pool of the cells. As shown in Table 1, the presence of histidine results in a lower ${ }^{14} \mathrm{C}$ level in the pool. Glucose has little or no effect in this regard. The combination of glucose and histidine is the same as histidine alone. The data of Table 2 indicate that the levels of incorporation of exogenously supplied amino acids were found to correspond to the levels in the pool after $1 \mathrm{hr}$. incubation. The contribution of permeability on the observed protein synthesis can be eliminated 
by considering only the rate of labelled amino acids incorporated into protein. Therefore, all further data will be presented as the percentage change in protein specific radioactivity over a given period of time.

Table 1. Effect of histidine and/or glucose on free amino acid pool size

Conditions were those of Fig. 5 except that $(a)$ the final concentrations of glucose and histidine were $0.06 \mathrm{M}$ and $0.04 \mathrm{M}$, respectively, $(b)$ instead of isolating the protein, the cells were washed three times with cold Bonner's salt solution before addition of trichloroacetic acid. The acid supernatant was retained for counting.

Additions

None
Histidine
Glucose
Histidine + glucose

\begin{tabular}{|c|c|c|}
\hline \multicolumn{3}{|c|}{ Stage* } \\
\hline Fruit & Preculmination & Preculmination \\
\hline \multicolumn{3}{|c|}{ C.p.m. in TCA supernatant } \\
\hline 380 & 332 & 501 \\
\hline 313 & 212 & 173 \\
\hline 375 & - & 414 \\
\hline 278 & - & 155 \\
\hline
\end{tabular}

* The amoebae were allowed to differentiate to the stage noted before any additions were made.

Table 2. Effect of pool size on amino acid incorporation into protein

The data herein presented were derived from the experiments described in the last column of Table 1 as well as Fig. 5. The stage of differentiation was preculmination.

\begin{tabular}{lrc}
\multicolumn{1}{c}{ Additions } & Relative specific activity \\
None & 100 & 100 \\
Histidine & $\mathbf{3 5}$ & $\mathbf{2 1}$ \\
Glucose & $\mathbf{8 3}$ & $\mathbf{8 5}$ \\
Histidine+glucose & $\mathbf{3 1}$ & $\mathbf{2 2}$
\end{tabular}

* The specific activity (c.p.m./ml.) of the acid supernatant with no additions was taken as 100 .

$\uparrow$ The specific activity (d.p.m./mg. protein) of the sample without added glucose or histidine was taken as 100 .

Protein was determined by the method of Sutherland, Cori, Haynes \& Olsen (1949). Radioactivity measurements were done in the Packard Tri-Carb Scintillation Spectrometer by an anthracene two-phase method (Steinberg, 1960) or a gel method (Gordon \& Wolfe, 1960; Kinard, 1957). Whenever necessary, the results of counting were corrected for quenching.

Mixed amino acids (hydrolysed Chlorella protein) were obtained from Isotopes Specialties Company, Burbank, California.

\section{RESULTS}

Non-specificity of stimulation of morphogenesis. When tested by the method outlined in the previous section, histidine stimulated the rate of development (Fig. 1) with the optimum concentration in the range of $0.02-0.05 \mathrm{M}$. It was found that a number of materials besides histidine, such as glucose, inorganic salts, and other amino acids, could stimulate fruit formation. Specific details are given in later sections. Possible mechanisms of action for these effects include ionic strength, buffer capacity, chelation, energy generation, and protein synthesis. 
lonic strength. Since sulphuric acid was used to adjust the $\mathrm{pH}$ of the histidine solutions, sulphate ion was tested for its ability to stimulate sorocarp formation. Figure 2 shows that sodium sulphate stimulated only slightly at a concentration of $0.01 \mathrm{~m}$ and not at all at the other concentrations tested. Potassium sulphate was quite stimulatory and sodium chloride enhanced fruit formation to a small extent. Magnesium ion and a mixture of sodium, potassium and calcium ions had a striking stimulatory effect at quite low molar concentrations. It should be pointed out that

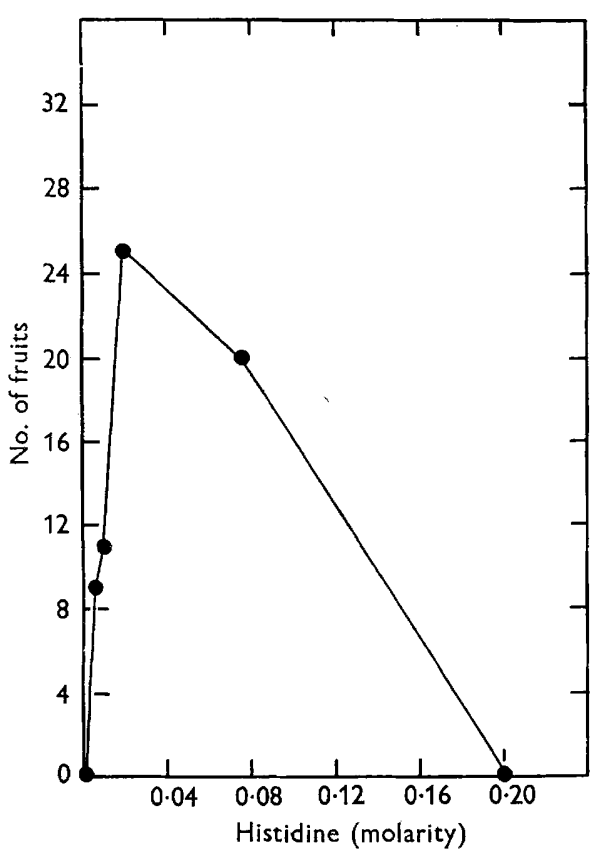

Fig. 1

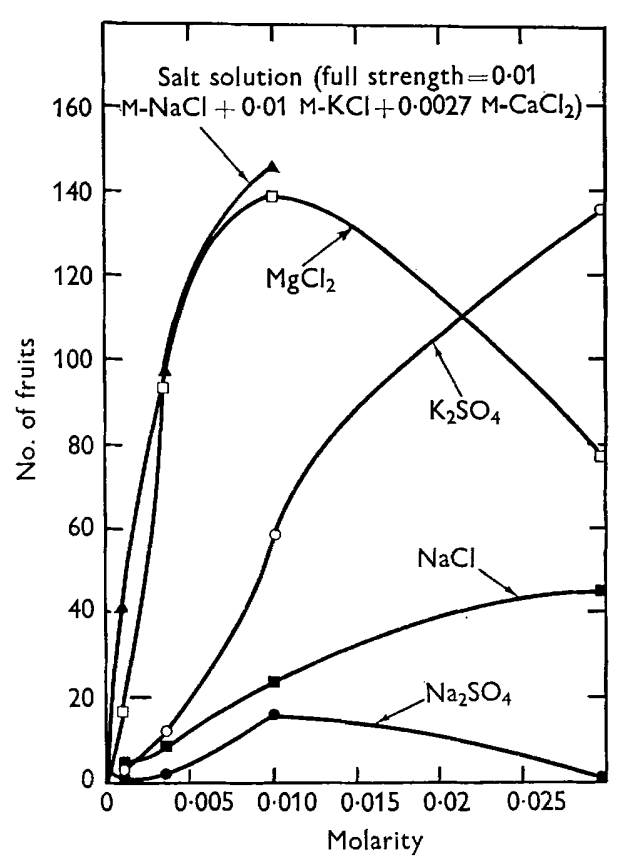

Fig. 2

Fig. 1. Stimulation of sorocarp formation by histidine. The procedure was that described under Methods except that three 0.01 ml. drops were added per Petri dish instead of six drops.

Fig. 2. Effect of various inorganic salts on sorocarp formation. The $\mathrm{NaCl}, \mathrm{KCl}, \mathrm{CaCl}_{2}$ solution used was that described by Bonner (1947).

$0.03 \mathrm{M}-\mathrm{Mg}^{2+}$ was extremely stimulatory towards the rate of fruit formation but the number of aggregative centres was markedly decreased so that apparent maximum stimulation occurred at a concentration of $0.01 \mathrm{M}-\mathrm{Mg}^{2+}$. In separate experiments (data not shown) $\mathrm{KCl}$ and $\mathrm{CaCl}_{2}$ were quite stimulatory when tested singly. As will be discussed under 'Buffer capacity' phosphate was also stimulatory. Ionic materials which were ineffective (or only slightly stimulatory) include alanine, glutamate, cysteine, glycine, aspartic acid, phthalate and the materials cited above.

Buffer capacity. As the $\mathrm{pK}$ of histidine is $6 \cdot 10$, it is possible that it might stimulate the rate of morphogenesis by virtue of its ability to buffer the medium. Clearly, maintenance of $\mathrm{pH}$ cannot be an absolute requirement since many substances stimulate while possessing little or no buffering capacity in the physiological $\mathrm{pH}$ 
range. Furthermore, the $\mathrm{pH}$ changes in media containing such materials were much the same as those in the unbuffered control (Table 3).

Figure 3 shows the effect of varying the $\mathrm{pH}$ on the stimulation by histidine: essentially, the enhancement by histidine was inversely proportional to the $\mathrm{pH}$.

\title{
Table 3. Environmental $\mathrm{pH}$ changes during the course of morphogenesis
}

\begin{abstract}
The amoebae obtained from the growth on one-half cookie sheet were washed in the manner described under Methods. The final volume of the cell suspension was $4.5 \mathrm{ml}$. Four-tenths $\mathrm{ml}$. samples of the cell suspension were spread on $2.5 \%$ washed agar $(10 \mathrm{ml}$.; $9 \mathrm{~cm}$. diam.) with additions as specified.

At the times indicated, at least three $\mathrm{pH}$ measurements were performed in separate locations on each plate simply by pressing the electrodes of a Beckman Model $\mathbf{H ~} \mathbf{p H}$ meter on the surface of the agar. The values given are the averages.
\end{abstract}

\begin{tabular}{|c|c|c|c|c|c|c|c|c|}
\hline \multirow[b]{2}{*}{ Additions } & \multicolumn{2}{|c|}{$1 \mathrm{hr}}$. & \multicolumn{2}{|c|}{$8.5 \mathrm{hr}}$. & \multicolumn{2}{|c|}{$20 \mathrm{hr}$. } & \multicolumn{2}{|c|}{$24.5 \mathrm{hr}$. } \\
\hline & Stage & $\mathrm{pH}$ & Stage & $\mathrm{pH}$ & Stage & $\mathrm{pH}$ & Stage & $\mathrm{pH}$ \\
\hline None & A* & $6 \cdot 7$ & Agg. & $6 \cdot 95$ & $\mathbf{S}$ & $7 \cdot 2$ & PC & $6 \cdot 9$ \\
\hline Histidine $0.04 \mathrm{M}$ & $\mathbf{A}$ & $6 \cdot 15$ & Agg. & $6 \cdot 1$ & $\mathbf{F}$ & $6 \cdot 25$ & F & $5 \cdot 9$ \\
\hline $\mathrm{KCl} 0.03 \mathrm{M}$ & $\mathbf{A}$ & $6 \cdot 8$ & Agg. & $6 \cdot 8$ & $\mathbf{P C}$ & $7 \cdot 2$ & $\mathbf{F}$ & $7 \cdot 3$ \\
\hline $\mathrm{MgCl}_{2} 0.01 \mathrm{M}$ & $\mathbf{A}$ & $7 \cdot 0$ & Agg. & $6 \cdot 85$ & PC & $7 \cdot 0$ & $\mathbf{F}$ & $6 \cdot 9$ \\
\hline $\begin{array}{l}\mathrm{NaCl} 0.01 \mathrm{M} \\
\mathrm{0.0027} \mathrm{MCl}\end{array}$ & $\mathbf{A}$ & $6 \cdot 35$ & Agg. & $6 \cdot 9$ & $\mathbf{P C}$ & $7 \cdot 0$ & $\mathbf{F}$ & $6 \cdot 9$ \\
\hline Glucose $0.05 \mathrm{M}$ & $\mathbf{A}$ & $6 \cdot 8$ & Agg. & $7 \cdot 3$ & C & $7 \cdot 1$ & $\mathbf{F}$ & $6 \cdot 9$ \\
\hline $\mathrm{NaCl} 0.03 \mathrm{M}$ & $\mathbf{A}$ & $6 \cdot 6$ & Agg. & $6 \cdot 6$ & PC & $7 \cdot 0$ & $\mathbf{F}$ & $6 \cdot 6$ \\
\hline
\end{tabular}

* Key to stages of differentiation: A, amoebae; Agg., aggregation; S, migrating pseudoplasmodium ; PC, preculmination ; C, culmination; F, fruit (or sorocarp).

Figure 4 indicates that phosphate ion was stimulatory at all concentrations tested. However, the combination of phosphate and $0.04 \mathrm{M}$-histidine was more stimulatory than either compound alone. When the $\mathrm{pH}$ of the phosphate was varied the results are those shown in Fig. 5. There was no trend of stimulation of development with changes in $\mathrm{pH}$, in marked contrast to the results obtained with histidine. It should be noted that phosphate was stimulatory regardless of the cationic component (i.e. $\mathrm{Na}^{+}$or $\mathrm{K}^{+}$). Since other sodium salts were not particularly stimulatory (Fig. 2), the phosphate ion itself was clearly stimulatory.

That phosphate was not unique with respect to the lack of a $\mathrm{pH}$ effect on development is shown in Fig. 5. Phthalate ion ( $\mathrm{pK}=\mathbf{5 . 5 1})$ appeared to be a metabolically inert buffer in this system. At every $\mathrm{pH}$ tested phthalate was neither stimulatory nor inhibitory regardless of the criteria considered (i.e. total centres, or fruits). In addition, histidine was stimulatory in the usual manner even when the medium was buffered with phthalate.

Chelation. That the rate of morphogenesis was limited by the presence of contaminating metal ions (capable of forming chelates) seems unlikely, since a variety of substances can stimulate the rate of development which would not be expected either to form chelates or relieve the inhibition due to such contaminants. However, histidine is an exception, as it forms very strong chelates with transition metals (Martell \& Calvin, 1952, p. 167). The only comparable natural amino acid that does so is cysteine. Experiments were therefore made to ascertain its ability to substitute for histidine (Table 4). Cysteine alone or glycine alone stimulated poorly or not at all at a $0.01 \mathrm{M}$ concentration when compared to $0.04 \mathrm{M}$-histidine. 
It should be noted that, at equimolar concentrations $(0.01 \mathrm{~m})$, histidine was quite stimulatory (Fig. 1).

Although other amino acids are not as efficient chelating agents as histidine and cysteine, a variety were tested for their ability to affect the morphogenesis of Dictyostelium discoideum. The result is given in Table 6 (see below). The chelating dipeptide, glycylglycine, was also tested, with the results shown in Fig. 6. When combined with $0.04 \mathrm{M}$-histidine, glycylglycine inhibited sorocarp formation at higher

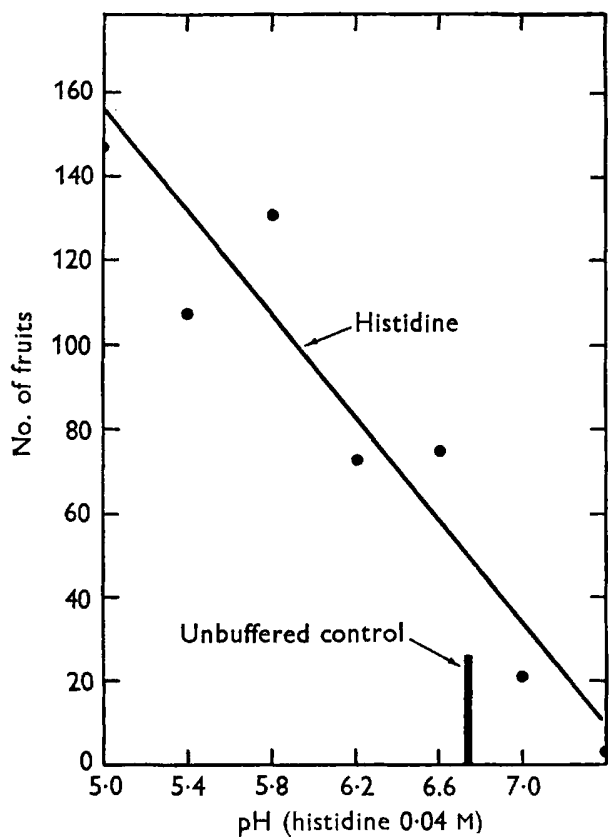

Fig. 3

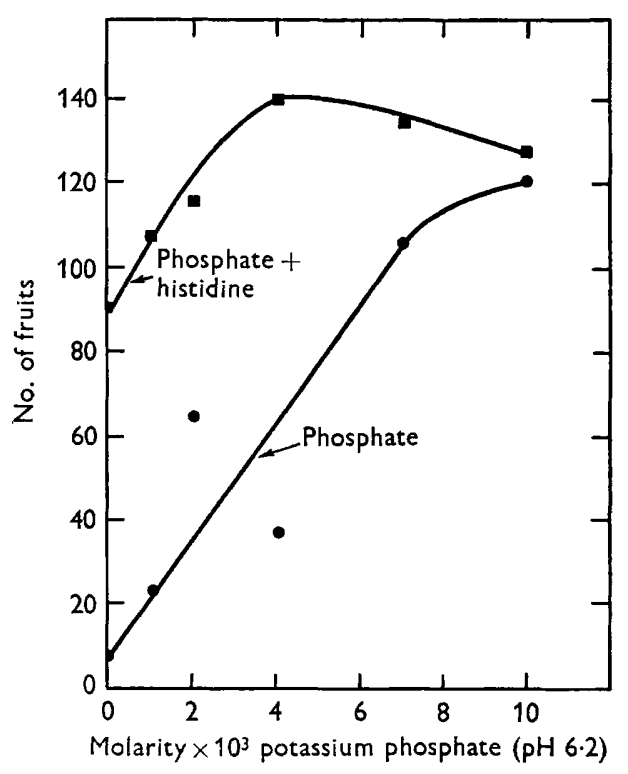

Fig. 4

Fig. 3. Variation of histidine stimulation at different hydrogen ion concentrations. The procedure was that described under Methods except that the $\mathrm{pH}$ of the histidine solutions were adjusted to those shown prior to addition of the agar.

Fig. 4. Stimulation of sorocarp formation by potassium phosphate (pH 6.2) with and without added histidine (0.04 M).

Table 4. Effect of cysteine and/or glycine on differentiation

See Methods for the experimental procedure.

\begin{tabular}{lrr}
\multicolumn{1}{c}{ Additions } & $\overbrace{\text { No. of fruits }}^{\text {Expt. 1 }}$ \\
None & \multicolumn{2}{c}{ Expt. 2 } \\
Cysteine $(0.01 \mathrm{M})$ & 0 & 10 \\
Glycine $(0.01 \mathrm{M})$ & $\mathbf{2 5}$ & $\mathbf{3 7}$ \\
Histidine $(0.04 \mathrm{M})$ & $\mathbf{1 1 7}$ & $\mathbf{1 2}$
\end{tabular}

concentrations. However, the total number of aggregative centres remained essentially unchanged. In contrast, glycylglycine alone inhibited centre formation in a manner proportional to the concentration. 
Protein synthesis. As development proceeds it is evident that new enzymatic activities must be expressed. It is conceivable that the rate-limiting step in morphogenesis is the synthesis of new types of proteins. Additionally, it might be expected that the rate of general protein synthesis could be limited by the availability of one or more amino acids. Krivanek \& Krivanek (1959) have shown by paper chromatography that histidine, proline, asparagine and phenylalanine are absent from the free amino acid pool but are present in the proteins of the developing slime mould. Proline was never found to stimulate morphogenesis either alone or in combination with any of the other three amino acids. Phenylalanine appeared to

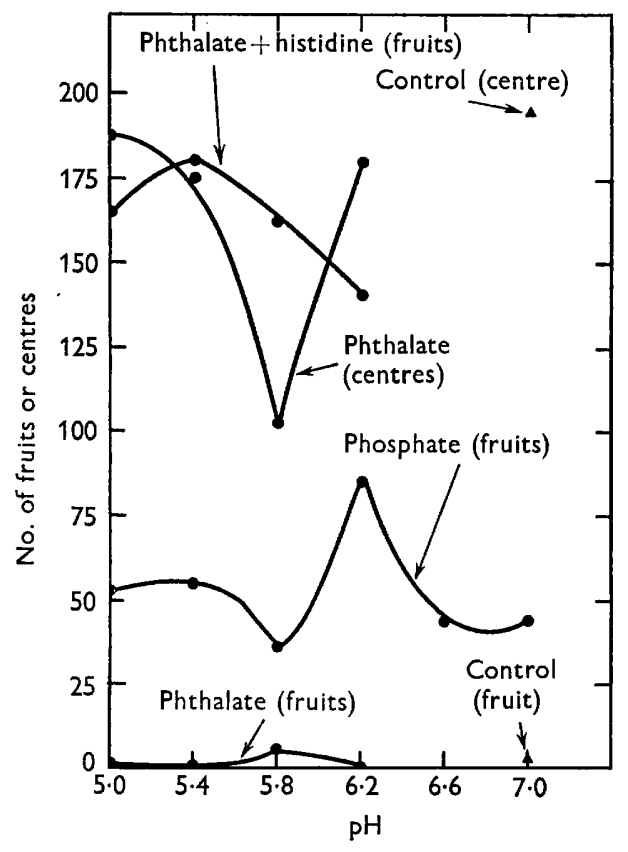

Fig. 5

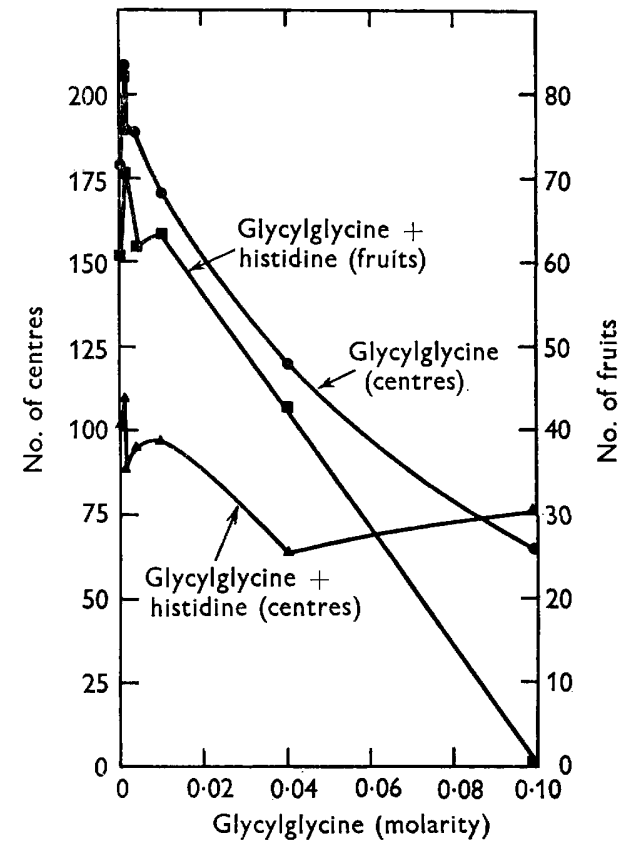

Fig. 6

Fig. 5. Effect of $\mathrm{pH}$ variation on morphogenesis. The $\mathrm{pH}$ of sodium phosphate and sodium phthalate solutions was adjusted as shown. The final concentration was $0.01 \mathrm{~m}$ in each case. The histidine final concentration was $0.04 \mathrm{M}$.

Fig. 6. Effect of glycylglycine on morphogenesis. Histidine was added in $0.04 \mathrm{M}$ concentration where indicated.

increase aggregative centre formation without affecting the rate of development (with or without added histidine) as did asparagine to a lesser extent. In neither case were the effects consistent. Aspartate, in one trial, had no effect. Therefore, histidine appeared to be unique among the single amino acids tested (i.e. glycine, cysteine, proline, phenylalanine, asparagine, aspartic acid, and glutamic acid) in its ability to stimulate markedly the rate of morphogenesis.

The effect of histidine on protein synthesis at the various stages of development is shown in Fig. 7. It may be seen that, initially, adding histidine inhibited the rate of protein synthesis when the control values were subtracted. The rate of protein synthesis upon the addition of histidine remained constant until preculmination 
while the rate in the absence of histidine decreased. A maximum in the rate of protein synthesis due to the presence of histidine was found at preculmination.

The presence of this maximum was confirmed in a more detailed experiment which was carried out over a briefer period with the median time at preculmination. The maximum was quite sharp and occurred at preculmination.

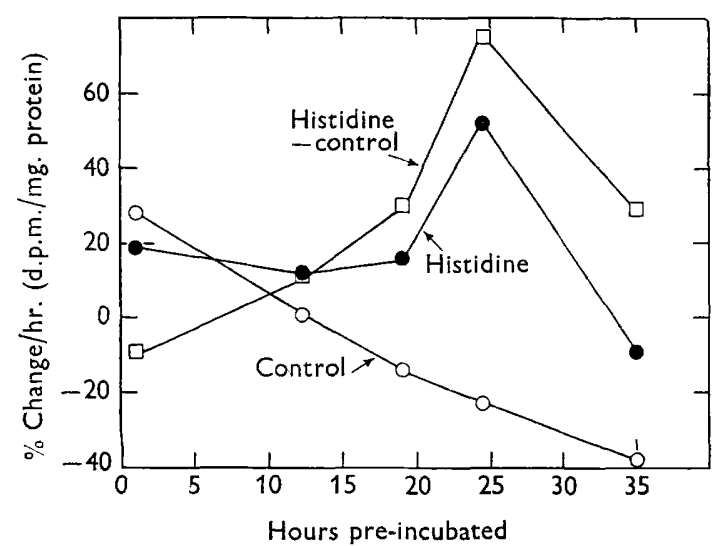

Fig. 7

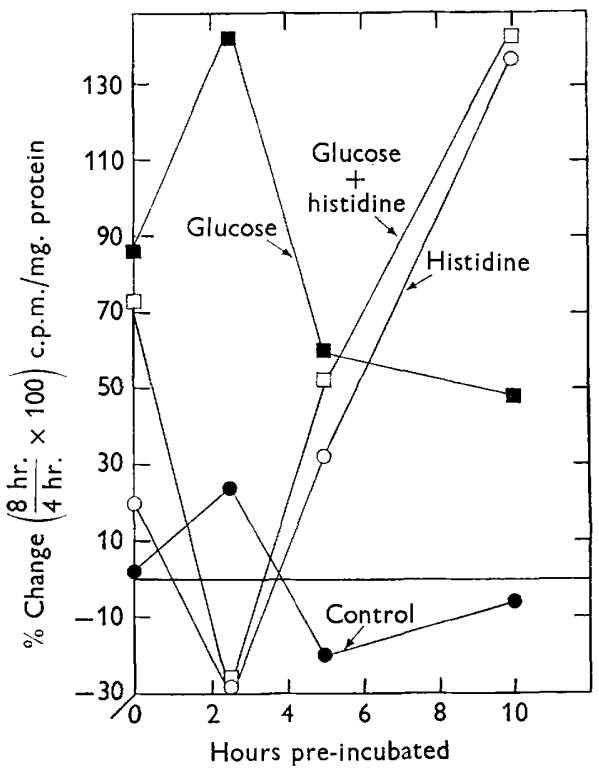

Fig. 8

Fig. 7. Effect of histidine on the rate of protein synthesis at various stages of development. Samples of amoebae were prepared and spread on $2.5 \%$ washed agar as outlined under Methods. The Petri dishes were incubated at $19^{\circ}$ until visual inspection showed that morphogenesis had proceeded to the desired stage. Next, to one series, $4.0 \mathrm{ml}$. of $0.04 \mathrm{M}$-histidine ( $\mathrm{pH} \mathrm{6.2)}$ and ${ }^{14} \mathrm{C}$-amino acids (0.05 $\mu \mathrm{C}$. $/$ sample; $0.65 \mu \mathrm{g}$ amino acids), dissolved in Bonner's salts, were added to each Petri dish. The histidine was omitted from the solutions added to the second series. The samples were incubated at $22^{\circ}$ for either 1 or 2 hr. and trichloroacetic acid added. Protein specific activities were determined as described under Methods, and the \% change between the specific activities at one and two hr. calculated. The stages of differentiation at the times indicated were: $1 \mathrm{hr} .=$ amoebae; $12 \mathrm{hr}$. = early aggregation; $19 \mathrm{hr}$. = early migrating pseudoplasmodium; $24.5 \mathrm{hr}$. = preculmination; $35 \mathrm{hr}$. $=$ fruit.

Fig. 8. Effect of glucose and/or histidine on the rate of protein synthesis. The conditions were those described in Fig. 7, except as follows: Four cookie sheets were harvested and the cell suspension volume (in Bonner's salts) was $130 \mathrm{ml}$. Four ml. samples were distributed in the Petri dishes and incubated for $0,2 \cdot 5,5$ or $10 \mathrm{hr}$. 'Then, $2 \mathrm{ml}$. Bonner salts containing ${ }^{14} \mathrm{C}$-mixed amino acids with glucose (final concentration $=0.05 \mathrm{M}$ ) and histidine ( $\mathrm{pH} \mathrm{6.2}$; final concentration $=0.04 \mathrm{M}$ ) as indicated were added. Duplicate samples were further incubated for 4 or $8 \mathrm{hr}$. before the trichloroacetic acid was added. The $\%$ change in specific activity of the isolated protein then was determined.

Figure 8 shows that, in contrast to histidine, glucose alone markedly stimulated the rate of protein synthesis at all stages. The interaction between glucose and histidine is complex. Glucose stimulated to a very small extent in the presence of histidine unless pre-incubation was omitted.

Figure 9 shows that, at the preculmination stage, glucose again stimulated the 
rate of protein synthesis while the combination of glucose and histidine was mutually exclusive. In fact, the combination of glucose and histidine could inhibit when compared to the rate observed with these compounds added separately. This was in direct contrast to their combined action on morphogenesis.

Energy generation. Since any anabolic process depends on available chemical energy and the morphogenesis of the cellular slime mould involves profound anabolic changes, tests were made of the requirements of the system for such energy limitations. Glucose was highly stimulatory to development regardless of the

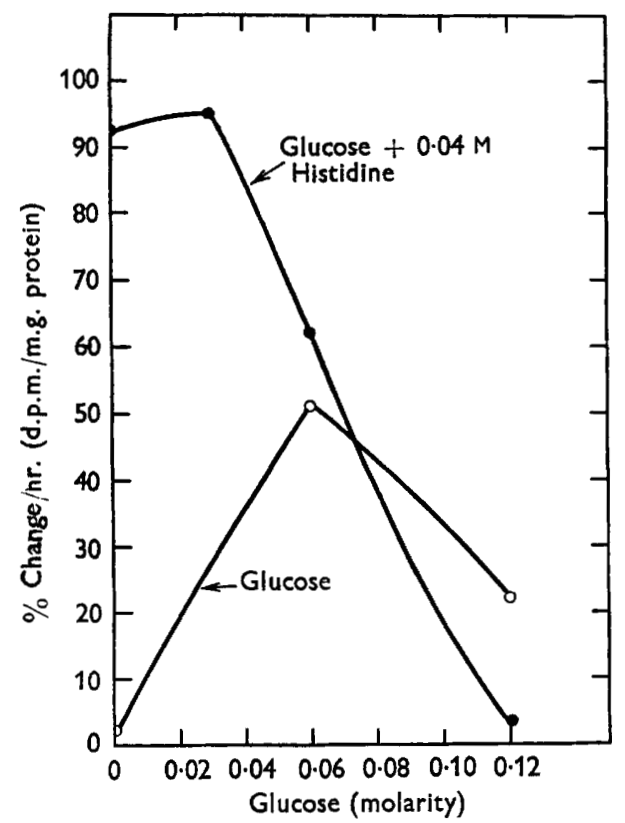

Fig. 9

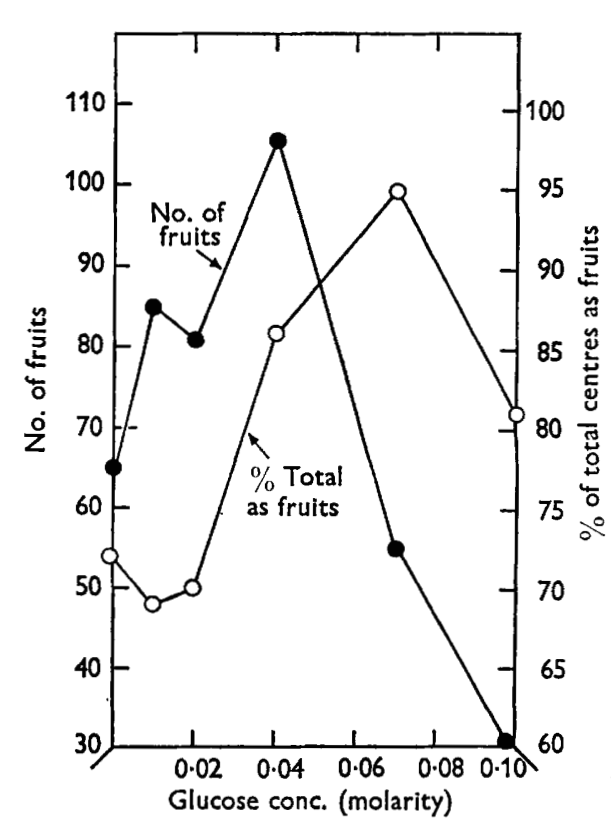

Fig. 10

Fig. 9. Effect of varying glucose concentrations, \pm added histidine, on the rate of protein synthesis. The conditions were those described in Fig. 7, except as follows : All incubations were carried out at $22^{\circ}$. No additions were made until the preculmination stage was apparent visually. Glucose was added to the final concentrations indicated. To one series of samples, histidine ( $\mathrm{pH} 6 \cdot 2$ ) was added to a final concentration of $0.04 \mathrm{M}$. Note that the initial point in each curve represents controls without added glucose.

Fig. 10. Stimulation of morphogenesis by varying concentrations of glucose.

criterion used (Fig. 10), but the optimum concentration varied with the criterion used. Presumably, at higher concentrations of glucose, the efficiency of response of the individual cells to the aggregative stimulus was enhanced in addition to the rate of morphogenesis. Alternatively, the efficiency of production of the stimulus (i.e. acrasin) may be enhanced. It will be recalled that $\mathbf{M g}^{2+}$ ion showed similar effects (Fig. 2).

The combined action of glucose and histidine is shown in Table 5. Glucose $(0.05 \mathrm{M})$ was stimulatory by itself. When combined with histidine the stimulation by the two was greatly increased. Thus, histidine can stimulate even in the presence of a good energy source such as glucose. 
That glucose is an energy source was demonstrated by Liddel \& Wright (1961), who found that it stimulated $\mathrm{O}_{2}$ utilization. A further comparison of the ability of various compounds to stimulate respiration with their ability to stimulate morphogenesis is given in Table 6. There was no correlation between respiration and morphogenetic effects.

Table 5. Effect of glucose and/or histidine on differentiation

\begin{tabular}{lrrrr} 
& Expt. 1 & Expt. 2 & Expt. 3 & Expt. 4 \\
\multicolumn{1}{c}{ Additions } & \multicolumn{4}{c}{ No. of fruits } \\
None & $\mathbf{1}$ & 6 & 0 & 15 \\
Histidine (0.04M) & $\mathbf{2 4}$ & 90 & 62 & 62 \\
Glucose (0.05 M) & $\mathbf{2 2}$ & 54 & 1 & 30 \\
Histidine + Glucose & 61 & 119 & 100 & 86
\end{tabular}

See Methods for the experimental procedure.

Table 6. Comparison of ability to stimulate respiration at the sorocarp stage with ability to stimulate morphogenesis

$\begin{array}{lcl}\text { Compound } & \begin{array}{c}\% \\ \text { Stimulation of } \\ \text { respiration* }\end{array} & \begin{array}{l}\text { Stimulation of } \\ \text { morphogenesis }\end{array} \\ \text { Glucose } & 100 & \text { Good } \\ \text { Glutamate } & \mathbf{3 0} & \text { None } \\ \text { Alanine } & 30 & \text { None } \\ \text { Cysteine } & 16 & \text { Slight } \\ \text { Histidine } & \text { Slight } & \text { Good } \\ \text { Glycine } & 0 & \text { Slight } \\ \text { Succinate } & 0 & \text { Moderate } \\ \text { Citrate } & 0 & \text { Inhibitory }\end{array}$

* Data taken from Liddel \& Wright (1961). All values are compared to glucose taken at $100 \%$.

\section{DISCUSSION}

The factors responsible for limiting the rate of morphogenesis in Dictyostelium discoideum are unknown at the present time. However, some broad generalizations may be deduced from the data in this paper.

The rate-limiting step or steps presumably plays a central role in the overall metabolism of the organism, since a wide variety of unrelated materials can markedly affect the rate of morphogenesis. In addition, the morphogenetic process itself is markedly resistant to metabolic imbalance, since the addition of high levels of single metabolites affect only the rate and not the course of development.

Ionic strength or tonicity do not appear to play a critical role in the development of Dictyostelium discoideum, as shown by the fact that, while many materials stimulate, a number of simple compounds are inert. Therefore, the species of molecule, and not simply the tonicity, affects the rate of morphogenesis.

The demonstration that the positive effect of phosphate and the lack of effect of phthalate on development are not ascribable to change in $\mathrm{pH}$ indicates that the environmental $\mathrm{pH}$ is unimportant (over the $\mathrm{pH}$ range of $5-7$ ). Bradley et al. (1956) first observed that the $\mathrm{pH}$ of the medium had no effect on aggregation in 
unbuffered media. In addition, the histidine stimulation increases with decreasing $\mathrm{pH}$, even to $\mathrm{pH} 5$, where this amino acid has little buffering capacity.

It seems evident that ability to chelate has no bearing on whether a compound will stimulate morphogenesis. Some monovalent metal ions stimulate while others do not. The same is true of chelating amino acids and glycylglycine. According to Gerisch (1961), $2.5 \times 10^{-3} \mathrm{M}$ ethylene-diaminetetracetate profoundly changes the course of development in Dictyostelium discoideum. At the level of $5 \times 10^{-3} \mathrm{M}$, this chelating agent was found to prevent sorocarp formation. No such aberrant morphogenesis was observed with the amino acids even though the concentrations were much higher.

It may be concluded that the rate of general protein synthesis does not control the rate of morphogenesis by limitation of the pool levels of one or more amino acids. If histidine or any of the other amino acids which are low or missing in the pool were limiting for protein synthesis, one would not expect such a variety of materials to stimulate the rate of development as do so.

Whether the synthesis of one or a few specific proteins, at a different rate from the general proteins, can control the rate of morphogenesis is not known, but it seems unlikely because glucose appears to stimulate protein synthesis before histidine does (Fig. 8). If histidine were limiting for the synthesis of even one critical protein, then nothing should substitute for this amino acid unless the substitute were a precursor of the histidine. If glucose addition led to the formation of histidine then it should stimulate no sooner than histidine itself. Also, the combined action of glucose and histidine on protein synthesis is in direct contrast to their action on the rate of development. That is, in the former case, the greater stimulation by the combination on morphogenesis is not observed.

Preliminary experiments on the size of the free histidine pool indicated that the level of intracellular pool is slightly lower with decreasing $\mathrm{pH}$. Previous work indicated that the stimulation by histidine of morphogenesis was higher with decreasing $\mathrm{pH}$. Since it was shown (Tables 1, 2) that histidine lowered the incorporation of extracellular mixed amino acids into the internal free pool, it is conceivable that the action of histidine is at a permeability level.

If the assumption is made that glucose is a good primary energy source in the system, then it would follow that histidine is not. This is because: $(a)$ histidine stimulates morphogenesis in the presence of high levels of glucose, $(b)$ histidine alone is a more efficient stimulant (on a molar basis) than glucose alone, $(c)$ histidine's effect on protein synthesis differs from that of glucose in quality and time of action. In fact, these compounds appear to be mutually antagonistic.

Obviously, none of the above preclude that histidine plays an indirect, but critical, role in energy metabolism. In all probability glucose serves as a primary energy source. Thus, it is possible that both stimulants affect the rate of morphogenesis by affecting the cells' energy metabolism, glucose doing so directly and histidine indirectly. This situation, in turn, may be responsible for their effect on protein synthesis.

The authors wish to thank Mr C. L. White, Epidemiology and Biometry Branch, National Institutes of Health, Bethesda 14, Maryland, for the statistical analysis. 


\section{REFERENCES}

BonNER, J. T. (1947). Evidence for the formation of cell aggregates by chemotaxis in the development of the slime mold Dictyostelium discoideum. J. exp. Zool. 106, 1.

Bonner, J. T. (1959). The Cellular Slime Moulds. Princeton, N.J.: University Press.

Bonner, J. T. \& DodD, M. R. (1962). Aggregation territories in the cellular slime molds. Biol. Bull., Woods Hole, 122, 13.

Braduey, S. G., Sussman, M. \& Ennis, H. L. (1956). Environmental factors affecting the aggregation of the cellular slime mold, Dictyostelium discoideum. J. Protozool. $3,33$.

GERISCH, G. (1961). Zellfunktionen und Zellfunktionswechsel in der Entwicklung von Dictyostelium discoideum. III. Getrennte Beeinflussung von Zelldifferenzierung und Morphogenese. Roux Arch. EntwMech. Organ. 153, 158.

Gordon, C. F. \& Wolfe, A. L. (1960). Liquid scintillation counting of aqueous samples. Analyt. Chem. 32, 574.

KrNaRD, F. E. (1957). Liquid scintillator for the analysis of tritium in water. Rev. sci. Instrum. 28, 293.

Krivanek, J. O. \& Krivanek, R. C. (1959). Chromatographic analysis of amino acids in the developing slime mold, Dictyostelium discoideum Raper. Biol. Bull., Woods Hole, 116, 265.

LIDDEL, G. U. \& WRight, B. E. (1961). The effect of glucose on respiration of the differentiating slime mold. Develop. Biol. 3, 265.

Martell, A. E. \& Calvin, M. (1952). Chemistry of the Metal Chelate. New York, N.Y.: Prentice-Hall, Inc.

Steinberg, D. (1960). A new approach to radioassay of aqueous solutions in the liquid scintillation spectrometer. Analyt. Biochem. 1, 23.

Sutherland, E. W., Cori, C. F., Haynes, R. \& Ousen, N. S. (1949). Purification of the hyperglycemic-glycogenolytic factor from insulin and from gastric mucosa. $J$. biol. Chem. 180, 825.

Wright, B. E. \& Anderson, M. L. (1960a). Protein and amino acid turnover during differentiation in the slime mold. I. Utilization of endogenous amino acids and proteins. Biochim. biophys. Acta, 43, 62.

Wright, B. E. \& Anderson, M. L. (1960b). Protein and amino acid turnover during differentiation in the slime mold. II. Incorporation of $\left({ }^{35} \mathrm{~S}\right)$ methionine into the amino acid pool and into protein. Biochim. biophys. Acta, 43, 67. 